\title{
Assessment of Potential Shale Gas Resources of the Bombay, Cauvery, and Krishna-Godavari Geologic Provinces, India, 2011
}

\begin{abstract}
Using a performance-based geologic assessment methodology, the U.S. Geological Survey estimated a technically recoverable mean volume of 6.1 trillion cubic feet of potential shale gas in the Bombay, Cauvery, and Krishna-Godavari Provinces* of India.
\end{abstract}

\section{Introduction}

The U.S. Geological Survey (USGS), in cooperation with the U.S. Department of State, is assessing the potential for unconventional oil and gas resources (shale gas, shale oil, tight gas, coalbed gas) in priority geologic provinces worldwide. This report summarizes the geologic model and assessment of potential shale gas resources of the Bombay, Cauvery, and Krishna-Godavari Provinces, India. These geologic provinces (Cambay, Cauvery, and Krishna-Godavari) are located along the margins of the Indian subcontinent (fig. 1) and contain the basins that were assessed in this study. The basins are interpreted to have originated as rift/sag basins and they control the distribution of Mesozoic and Cenozoic source rocks as well as the shale gas resources in the respective geologic provinces.

\section{Cambay Basin}

The upper Paleocene to middle Eocene Cambay Shale is interpreted to be a major source rock in the Cambay Basin (Directorate General of Hydrocarbons, Cambay Basin, written commun., 2009). Cambay Shale was deposited in deltaic and nearshore marine environments in the northern and central parts of the basin, and in deeper marine environments in the southern part of the basin. Therefore, this source rock presumably contains greater amounts of type II kerogen southward in the basin. Thermal maturity increases from north to south across the basin. Although the Cambay Shale is in the oil-generation window in the north, it is in the gas-generation window in the south. At the base of the shale, vitrinite reflectance $(\mathrm{Ro})$ values are greater than 1.1 percent. Total organic carbon contents (TOC) are greatest in the basin depocenters, with concentrations greater than 4 weight percent.

\section{Cauvery Basin}

Potential source rocks in the Cauvery Basin include shales of the Lower Cretaceous Andimadam Formation and the Lower to Upper Cretaceous Sattapadi Shale and its stratigraphic equivalents (Directorate General of Hydrocarbons, Cauvery Basin, written commun., 2009). The shales are interpreted to have been deposited in marine environments. The Sattapadi Shale contains 2 to 2.5 weight percent TOC and is thermally mature for hydrocarbon generation in deeper parts of the basin. Ro values vary from approximately 1.0 percent to as much as approximately 1.5 percent. Kerogen types are predominantly type III with minor amounts of type II.

"The term "provinces" refers to geologically defined units assessed by USGS for the purposes of this report and carries no political or diplomatic connotation.

Figure 1. Locations of the Bombay, Cauvery, and Krishna-Godavari Provinces in India (red) and the areas of the shale gas assessment units (AUs) (green) that were assessed in this study. Maps of AUs were based on data from Directorate General of Hydrocarbons (written commun., 2009). Dashed boundaries indicate lines of control and area of Indian claim.

\section{Krishna-Godavari Basin}

The Upper Jurassic to Cretaceous Raghavapuram Shale and its stratigraphic equivalents are inferred to be the main source rock for much of the Krishna-Godavari Basin (Directorate General of Hydrocarbons, Krishna-Godavari Basin, written commun., 2009). The Raghavapuram Shale was deposited in marginal marine to inner shelf environments, whereas the stratigraphically equivalent Chintalapalli Shale accumulated under bathyal conditions. The shale contains as much as 2.4 weight percent TOC, and its thermal maturity ranges from immature to mature with respect to gas generation. Type III kerogen is most common, but type II is present where the shale was deposited under deeper marine conditions.

\section{Geologic Model for Assessment}

The geologic model that forms the basis for the assessment of Bombay, Cauvery, and Krishna-Godavari Provinces is that the shales are self-sourced. Gas was generated in Mesozoic and Cenozoic organic-rich shales and filled matrix and organic matter porosity in the same shales. Evaluations for each of the shale gas systems and areas to be assessed used five criteria: (1) average TOC of 2 weight percent or greater;

(2) presence of type I, II, or IIS kerogen; (3) thermal maturity equivalent to at least 1.1 percent Ro; (4) presence of thermogenic gas; and (5) net source rock thickness of 15 meters or more. All five of these criteria must be present at one place to continue with an assessment (Charpentier and Cook, 2011).

For each of the assessed provinces, the presence of organic-rich shales, the presence of type II in relation to type III kerogen, the potential for matrix storage of gas, and the thermal windows for oil in relation to gas generation are all subject to significant geologic uncertainty. Consequently, shale-gas accumulations in the United States were used as geologic and engineering analogs in the USGS assessment of these provinces (Charpentier and Cook, 2011). Analog data from U.S. accumulations included estimated ultimate recoveries from shale-gas wells, average drainage areas of wells (cell sizes), and ranges of success ratios. Key assessment input data are listed in table 1.

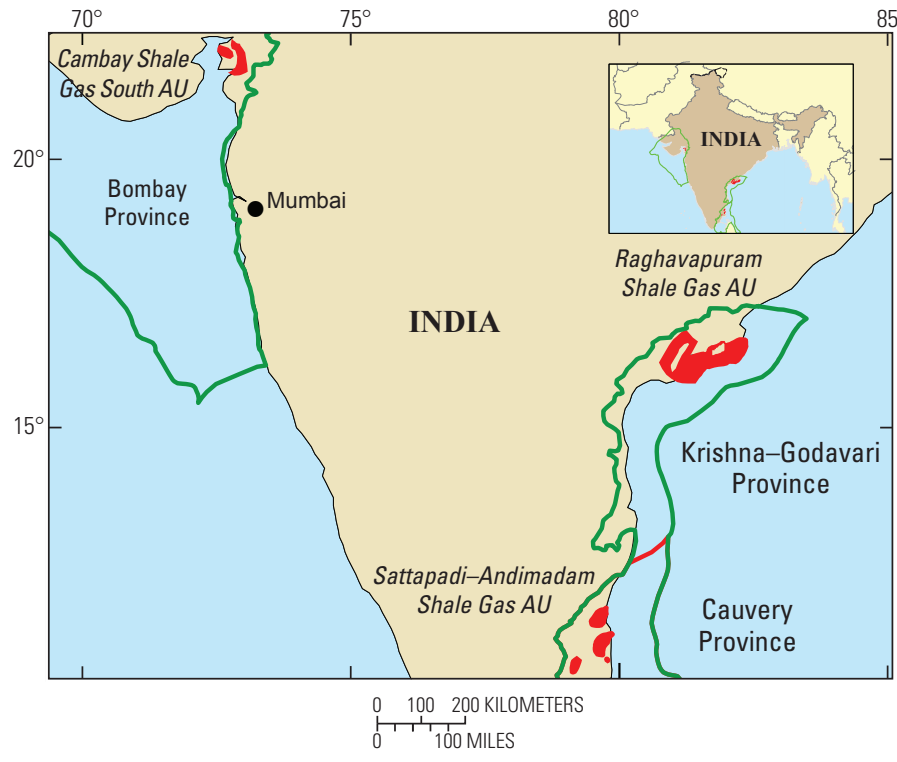


Table 1. Key assessment input data for shale gas assessment units in the Bombay, Cauvery, and Krishna-Godavari Provinces. EUR (estimated ultimate recovery per well), cell size, and success ratios are from U.S. shale gas and shale oil analogs. MMB, million barrels; BCF, billion cubic feet; $A U$, assessment unit. Minimum, mode, and maximum values represent the uncertainty around the mean values, and do not reflect the total variation in these parameters. Areas of AUs were calculated from maps produced by Directorate General of Hydrocarbons (written commun., 2009).

\begin{tabular}{|l|c|c|c|c|c|c|c|c|}
\hline \multirow{2}{*}{ Assessment input data } & \multicolumn{4}{c|}{ Cambay Shale Gas South AU } & \multicolumn{4}{c|}{ Sattapadi-Andimadam Shale Gas AU } \\
\cline { 2 - 10 } & Minimum & Mode & Maximum & Calculated mean & Minimum & Mode & Maximum Calculated mean \\
\hline Potential production area of AU (acres) & 110,000 & 230,000 & 350,000 & 230,000 & 200,000 & 300,000 & 650,000 & 383,333 \\
\hline Average drainage area of wells (acres) & 120 & 150 & 180 & 150 & 120 & 150 & 180 & 150 \\
\hline Average EUR (BCF, gas) & 0.2 & 0.6 & 2.5 & 0.7 & 0.2 & 0.4 & 2.5 & 0.54 \\
\hline Success ratios (percent) & 75 & 90 & 95 & 87 & 75 & 90 & 95 & 87 \\
\hline
\end{tabular}

\begin{tabular}{|l|c|c|c|c|}
\hline \multirow{2}{*}{\multicolumn{1}{c|}{ Assessment input data }} & \multicolumn{4}{c|}{ Raghavapuram Shale Gas AU } \\
\cline { 2 - 5 } & Minimum & Mode & Maximum & Calculated mean \\
\hline Potential production area of AU (acres) & 345,000 & 700,000 & $2,000,000$ & $1,015,000$ \\
\hline Average drainage area of wells (acres) & 120 & 150 & 180 & 150 \\
\hline Average EUR (BCF, gas) & 0.2 & 0.6 & 2.5 & 0.7 \\
\hline Success ratios (percent) & 75 & 90 & 95 & 87 \\
\hline
\end{tabular}

Table 2. Assessment results for potential shale gas resources in the Bombay, Cauvery, and Krishna-Godavari Provinces (technically recoverable, continuous resources).

[MMB, million barrels; BCF, billion cubic feet. Results shown are fully risked estimates. For gas fields, all liquids are included under the natural gas liquids (NGL) category. F95 denotes a 95-percent chance of at least the amount tabulated. F50 denotes a 50-percent chance, and F5 denotes a 5-percent chance. Other fractiles are defined similarly. Fractiles are additive under the assumption of perfect positive correlation. TPS, total petroleum system; AU, assessment unit. Gray shading indicates not applicable]

\begin{tabular}{|c|c|c|c|c|c|c|c|c|c|c|c|c|c|c|}
\hline \multirow{3}{*}{$\begin{array}{l}\text { Geologic provinces, } \\
\text { total petroleum systems (TPS), } \\
\text { and assessment units (AU) }\end{array}$} & \multirow{3}{*}{$\begin{array}{c}\text { AU } \\
\text { probability }\end{array}$} & \multirow{3}{*}{$\begin{array}{l}\text { Field } \\
\text { type }\end{array}$} & \multicolumn{12}{|c|}{ Total undiscovered resources } \\
\hline & & & \multicolumn{4}{|c|}{ Oil (MMB) } & \multicolumn{4}{|c|}{ Gas (BCF) } & \multicolumn{4}{|c|}{ NGL (MMB) } \\
\hline & & & F95 & F50 & F5 & Mean & F95 & F50 & F5 & Mean & F95 & $\mathrm{F} 50$ & F5 & Mean \\
\hline \multicolumn{15}{|c|}{ Bombay Province, Mesozoic-Cenozoic Composite TPS } \\
\hline Cambay Shale Gas South AU & 1.0 & Gas & & & & & 383 & 787 & 1,966 & 924 & 12 & 27 & 69 & 31 \\
\hline \multicolumn{15}{|c|}{\begin{tabular}{|l} 
Cauvery Province, Mesozoic-Cenozoic Composite TPS \\
\end{tabular}} \\
\hline Sattapadi-Andimadam Shale Gas AU & 1.0 & Gas & & & & & 444 & 887 & 2,660 & 1,123 & 14 & 31 & 95 & 39 \\
\hline \multicolumn{15}{|c|}{ Krishna-Godavari Province, Mesozoic-Cenozoic Composite TPS } \\
\hline Raghavapuram Shale Gas AU & 1.0 & Gas & & & & & 1,406 & 3,387 & 9,133 & 4,080 & 28 & 73 & 207 & 90 \\
\hline \begin{tabular}{|l|} 
Total continuous resources \\
\end{tabular} & & & & & & & & & & 6,127 & & & & 160 \\
\hline
\end{tabular}

\section{Resource Summary}

The results of the USGS assessment of potential shale gas resources in the Bombay, Cauvery, and Krishna-Godavari Provinces of India are listed in table 2 . In summary, the estimated mean volumes of technically recoverable petroleum resources are as follows: (1) for the Cambay Shale Gas South Assessment Unit (AU) of the Bombay Province-924 billion cubic feet of gas (BCFG; range, 383 to 1,966 BCFG) and 31 million barrels of natural gas liquids (MMBNGL; range, 12 to 69 MMBNGL); (2) for the Sattapadi-Andimadam Shale Gas AU in the Cauvery Province-1,123 BCFG (range, 444 to 2,660 BCFG) and 39 MMBNGL (range, 14 to 95 MMBNGL); and (3) for the Raghavapuram Shale Gas AU of the Krishna-Godavari Province-4,080 BCFG (range, 1,406 to 9,133 BCFG) and $90 \mathrm{MMBNGL}$ (range, 28 to $207 \mathrm{MMBNGL}$ ). The ranges of resource estimates for shale gas reflect the considerable geologic uncertainty in these assessment units.

\section{Acknowledgments}

We thank Chandra Bhan Singh of the Indian Ministry of Petroleum and Natural Gas; S.K. Srivastava, Director General of the Directorate General of Hydrocarbons, as well as the staff of the Directorate General of Hydrocarbons, including Atanu Banerjee, Malcolm Lall, S. Rath, Amitava Roy, S.C. Sarma, B.J. Hazarika, and Sanjay Chawla; and members of Oil and Natural Gas Company Oil India, Ltd., and Gas India, Ltd., for sharing data and for educating us on the petroleum geology of the basins of India prior to the USGS assessment.

\section{Reference Cited}

Charpentier, R.R., and Cook, T.A., 2011, USGS methodology for assessing continuous petroleum resources: U.S. Geological Survey Open-File Report 2011-1167, 73 p.

\section{Indian Basins Assessment Team}

Timothy R. Klett, Christopher J. Schenk, Craig J. Wandrey, Michael Brownfield, Ronald R. Charpentier, Troy Cook, Donald L. Gautier, and Richard M. Pollastro.

\section{For Further Information}

Supporting geologic studies of total petroleum systems and assessment units, and reports on the methodology used in the assessment of the Bombay, Cauvery, and KrishnaGodavari Provinces, and assessment results are available at the USGS Energy website: http://energy.usgs.gov/OilGas/ AssessmentsData/WorldPetroleumAssessment.aspx. 